\title{
Tourists' Attitude Toward Beach Management Systems in Bangladesh and Reorienting the Strategies for Sustainable Development
}

\author{
Syed Towfiq Mahmood Hasan* \\ Associate Professor, Department of Business Administration, Shahjalal University of Science and Technology, \\ Sylhet-3114, Bangladesh \\ Golam Morshed Shahriar Tanim \\ Lecturer, Army Institute of business Administration, Jalalabad Cantonment. Sylhet, Bangladesh
}

\begin{abstract}
The tourism sector in Bangladesh is one of the key potential sectors which can be a key contributing sector of the economy of Bangladesh. But, flourishment of this sector mainly depends on the tourist revisit intention. The revisit intension is determined by the tourists' psychology and prevailing experience of the tourist. The main purpose of this study is to determine the tourist psychology on the beach management systems and develop some strategies to increase tourist satisfaction and ensure sustainable development of this sector. This study mainly applied mixedmethod (quantitative as well as qualitative) in particular, survey study method as a quantitative technique and FGD as a qualitative method have been used in collecting necessary data. Collected data were analyzed by using SPSS and qualitative data analysis techniques to measure the research objectives. The study found the beach management systems in Bangladesh is at a reasonable level by considering different variables. The study concludes that tourist's attitude on food and accommodation facilities, security issues, hygiene and sanitation, emergency and health care services, tourist guide and information, transport facilities, and shopping facilities are not at a satisfactory level while all these factors other than shopping facilities significantly affect the satisfaction level of the domestic and international tourist.
\end{abstract}

Keywords: Tourist Psychology, Beach Management Systems, Tourist Satisfaction

DOI: $10.7176 / \mathrm{EJBM} / 12-36-05$

Publication date: December $31^{\text {st }} 2020$

\subsection{Introduction}

Tourism is one of the most notable fastest growing industries, all over the world in considering employment generation and contribution to national GDP (Davenport \& Davenport 2006; Hemmati \& Koehler 2000). The tourism industry may become a tool for third world countries to combat poverty by generating income and employment (Tooman, 1997); as well as diversifying the economy (Emaad, 2007).On the other hand, third world countries often possess unparalleled natural beauty. Previous research found that developing countries are deprived of benefits derived from tourism and suggested proper planning that includes the socio-cultural, economic, and environmental factors (Butler 1974; de Kadt 1979; Edelmann 1975; Hyma \& Wall 1979; Jafari 1974; Sadler \& Archer 1974). Subsequently, tourism practitioners and international organizations started working with tourism and began to use it as an effective tool for poverty alleviation and showed that community participation in the tourism planning process is advocated as a way of implementing sustainable tourism (Okazaki, 2008). Bangladesh has all the potential to be an attractive tourist destination in the Asia Pacific region but it has not created such an environment like its neighboring country. The country has three beaches including the world's largest sea beach and few famous islands which are tourist attractions. Ansari et al. (2006) opined that tourism activities in the Island like St. Martin's Island have positive impacts on the economic and social environment of the island as well as on the economy of the country. For attracting international beach tourists and saving ecological balance, beach management can be a pertinent issue. Beach management means road map to attract beach tourists for visiting and revisiting, establishing beach infrastructure, monitoring visitors, ensuring beach security (at the time of recreation and off-time recreation visiting), etc.

There are many types of tourist in the tourism industry but one of the vital aspects is that the highest percentages of tourists in the world are beach tourists. Generally, those who have short leisure time or recreational scope choose to visit different beaches for recreation or other purposes (Ansari et al. 2006)). But many cases visitors think beach tourism is very much risky than other types of tourism because of security on the beach at the time of recreation, swimming, walking, sports, water protocol, etc. Even in Bangladesh, four parents out of ten do not directly permit their school, college, and university going son and daughter to be a beach tourist. Considering economic impending and other benefits from tourism industries in Bangladesh, only a few numbers of studies have been done to explore tourists' satisfaction in this particular region. So, this is very urgent to reorient the strategies for beach management to attract the domestic as well as the international tourists which can contribute to the 
sustainable development of the country. There is huge scope for the country to declare the tourism sector especially beach tourism as the second contributing sector after RMG in Bangladesh (Ahmed et al., 2010). Many studies completed on focusing on tourism potential (Das \& Chakrabotry, 2012), economic prospects and constraints (Sofique et al., 2009), tourism site and destination management (Ahmed et al., 2010), tourism management and managerial problem, as well as various tourism promotional activities in Bangladesh. Among the previous studies, most of them are based on an overall general evaluation of tourism industries in Bangladesh. Again previous studies have not considered the expectation and attitudes of the local and international tourists or visitors to develop the strategies related to the progress of this sector. The present study will look into measuring attitudes toward beach management systems for developing this sector. This research will help the policy-makers to be updated, at least to some extent, of the tourism impacts being felt and encourage to ameliorate the negative sides and bridge the existing gaps by reviewing the necessary policies and their strict but positive enforcement in the area for a sound, systematic and sustainable tourism development.

\subsection{Literature Review:}

Researchers explained tourist satisfaction as the results of the experiences of tourists on visited destinations based on prior expectations. Satisfaction is recognized as a post-purchase construct that is related to the extent of a consumer's likes or dislikes about a service or product after experiencing it (Sukiman et al., 2013). Tourist satisfaction is an important factor in the successful marketing of heritage and cultural tourism because it affects the selection of destination, consumption of service, and decision to revisit (Cooper and Jacson, 1989). There are many reasons that make tourists satisfied with their visit, containing the quality of services delivered, such as infrastructure, safety, hygiene, natural situation, consumer protection, and also accessibility (Salleh et al., 2013). Generally, tourist satisfaction bases on twelve variables such as accommodations, shopping facilities, and restaurant facilities, quality of accommodation, personal safety, tourist information, beach cleanness, and state of the roads, beach promenades, drinkable water, and traffic flow and parking facilities (Wang and Qu, 2006). Another study stated that most of the tourists were satisfied with facilities related to destination management, with a natural attraction to the beach and relaxation facilities provided by the destination (Hasan and Shahnewaz, 2014). The outcome of this empirical research is to better understand tourists' expectations and formulate improved strategies, regional policy, and a balanced approach toward sustainable tourism development in the region. For developing an efficacious traveler destination, the stakeholders are required to communicate an integrated plan. If all stakeholders do their part accordingly and remain responsible for their own actions, the sectors of tourism will surely embellish. Proper facilities and accommodation are one of the first conditions for implementing sustainable tourism. It also requires assurance of the booming of a destination and continuous investment to keep the pace of development (Weaver, 2006). It also needs to ensure the ecological balance, conservation, and biodiversity. Sustainable tourism should not change or spoil the cultural resources, national and social values. Community participation in the tourism planning process is advocated as a way of implanting sustainable tourism. Tourism industry in Bangladesh has not got a solid footing to "taken off" despite all the efforts and measures from the government and other private agencies (Tuhin and Majumder, 2015). There are several tourist facilities in Bangladesh. But in some cases, information about these are not available to the tourists. Bangladesh Parjatan Corporation (BPC) should change its marketing strategy to build up a good image of Bangladesh (Hasan, 1992). To support tourism in the country; Biman has failed to understand the customers' real want, satisfaction, and other requirements ( Ferdous and Faisal, 2014). In Bangladesh, sustainable growth in the tourism sector should include conservation of different tourist sites which has a flourishing potentiality, easy access ability of tourists by air, road and sea, hygienic foods have to be offered, services provided by the hotel should be standard, amusement facilities should be available for tourists and public and emergency health services facilities should be there. Sustainable tourisms' aim is to bring a positive experience for tourism companies, local people, and national and international tourists.

\subsection{Objectives of the study}

The core objective of the study is to investigate the tourists' attitude toward the beach management systems of Bangladesh. The specific objectives are:

i. To investigate the existing beach management systems of Bangladesh.

ii. To measure the satisfaction level of domestic as well as international tourists about beach management systems.

iii. To recommend the action plan and reorienting the strategies for better management of the beach for an increasing number of visitors and national income and finally for the sustainable development of the country.

\subsection{Research Methodology}

In order to achieve objectives, mixed-method (quantitative as well as qualitative) in particular, survey study 
method as a quantitative technique and FGD as a qualitative method have been used in collecting necessary data. Population and Sample: The study examined the tourists' attitude toward beach management systems of Bangladesh. Thus every visitor was considered as an individual case. So, all the visitors of different beaches are the population of this study. There are five beaches including Saint Martin Island in Bangladesh. Among them, Cox's bazaar is the longest in the world. All these beaches were selected purposively for taking samples while respondents (visitors) were selected using a random sampling method. Again two FGD were conducted with the policymaker of the tourism industry.

Sources of data and their collection: The study considered both primary and secondary data. Primary data were collected from the respondents (visitors or tourists and management level people of tourism board) using a semistructured questionnaire and the main source of secondary data were the annual reports of the tourism board. Other secondary sources are journals, books, and related publications.

Analysis of data: The data obtained through the various methods discussed above would be qualitative as well as quantitative. Relationships between various variables were explored by using descriptive statistics and regression analysis.

\subsection{Current Scenario of Tourism in Bangladesh}

Bangladesh's tourism sector has experienced growth in recent years, particularly in the last decade. However, the growth pattern has been erratic implying unstructured development and perhaps also the lack of proper planning from the government. Falling of tourist arrival is an ominous sign for the industry and demands further investigation by the authorities to identify the reasons behind this. Some of the reasons which are frequently pointed out by tourists for not visiting Bangladesh are the lack of adequate facilities in terms of accommodation as well as transport linkages, and the political instability/security issue. (Khondker, 2014)

Table -01: Position of Bangladesh among neighbor countries in world T\&T competitiveness index (Global $T$ \& $T$ competitive Ranking (out of 140 countries)

\begin{tabular}{|c|c|c|c|c|c|c|c|c|c|}
\hline Country & 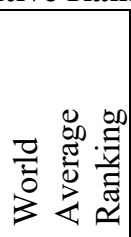 & 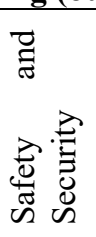 & 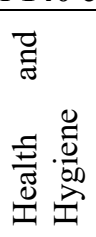 & 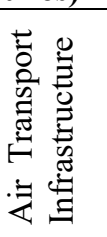 & 总 & 㫐莺 & 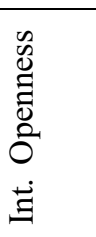 & 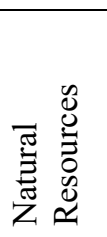 & 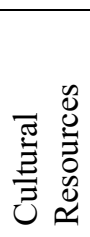 \\
\hline Bangladesh & 125 & 123 & 107 & 113 & 133 & 116 & 104 & 107 & 74 \\
\hline India & 40 & 114 & 104 & 32 & 110 & 112 & 55 & 24 & 9 \\
\hline Nepal & 103 & 100 & 85 & 105 & 124 & 124 & 87 & 27 & 117 \\
\hline Sri Lanka & 64 & 59 & 71 & 68 & 94 & 100 & 67 & 31 & 72 \\
\hline Pakistan & 124 & 133 & 101 & 99 & 125 & 126 & 114 & 120 & 59 \\
\hline Philippines & 79 & 126 & 92 & 65 & 87 & 86 & 60 & 37 & 60 \\
\hline
\end{tabular}

\section{Source: The Travel \& Tourism Competitiveness Report, World Economic Forum (2017)}

In recent years, Many Bangladeshi Tourists travel abroad. Especially countries in the South Asian region, like Thailand, Malaysia, Singapore, and India, etc. The main reasons for traveling outbound are rising per capita income and offering extremely lucrative packages for traveling outside Bangladesh. For medical purposes, Bangladeshi tourists are more interested in traveling to Thailand, Singapore, and India. The proliferation in outbound travel also indicates that many domestic tourists prefer to travel abroad rather than their own country. This means the local tourist spots/facilities are unable to attract domestic tourists in large numbers. In Bangladesh, tourist spots are not provided with facilities that other developed country provides. For that reason, many Bangladeshi tourists are getting attracted to foreign countries. 
Table -02: Tourist arrival and departures in different periods of time

\begin{tabular}{|c|c|c|c|c|}
\hline Year & \multicolumn{2}{|c|}{ Number of Tourist } & \multicolumn{2}{c|}{ Growth (\%) } \\
\hline & Arrivals & Departures & Arrivals & Departures \\
\hline 1995 & 156000 & 830000 & - & - \\
\hline 1996 & 166000 & 911000 & 6.4 & -4.9 \\
\hline 1997 & 182000 & 866000 & 9.6 & 14.5 \\
\hline 1998 & 172000 & 992000 & -5.5 & 11.2 \\
\hline 1999 & 173000 & 1103000 & 0.6 & 2.3 \\
\hline 2000 & 199000 & 1128000 & 15.0 & -4.7 \\
\hline 2001 & 207000 & 1075000 & 4.0 & 7.7 \\
\hline 2002 & 207000 & 1158000 & 0.0 & 22.1 \\
\hline 2003 & 245000 & 1414000 & 18.4 & 10.7 \\
\hline 2004 & 271000 & 1158000 & 10.6 & 2.9 \\
\hline 2005 & 208000 & 1767000 & -23.2 & 2.9 \\
\hline 2006 & 200000 & 1819000 & -3.8 & -62.4 \\
\hline 2007 & 289000 & 2327000 & 44.5 & 157.6 \\
\hline 2008 & 467000 & 875000 & 61.6 & - \\
\hline 2009 & 267000 & 2254000 & -42.8 & $\mathbf{1 4 . 8}$ \\
\hline 2010 & 303000 & - & 13.8 & $\mathbf{6 . 8}$ \\
\hline
\end{tabular}

(Source: Bangladesh Bank)

\subsection{Present Scenario of Beach Tourism in Bangladesh}

Several millions of people visit beach areas every year, and the number of people is increasing. After the independence of Bangladesh in 1971, tourism at Cox's Bazar started in a limited way by the modest efforts of the government. However, in recent years, Cox's Bazar experienced a huge growth in tourism. During the peak season (October to April) about 2 million tourists visit Cox's Bazar and it is expected that the figure will reach at least at 15 million by the year 2030 (UDD 2015). Along with the world's largest sea beach in Cox's Bazar, Bangladesh has distinct tourism places like the Kuakata sea beach where one can enjoy the sun-rise and sun-set from the same place. Bangladesh has the coral island at Saint Martin. By developing proper tourist facilities, Bangladesh can earn a huge amount of foreign currency, generate employment, reduces poverty, and the improvement of the quality of life for its people. It has the potential to contribute to economic and social development, especially to the developing countries, and its emergence as a vital force for the promotion of international understanding, peace, and prosperity. Given the economic potential and other benefits from tourism industries in Bangladesh, little has been done to investigate tourists' satisfaction in this particular region. Another study was carried out by Zaheer et al. (2011), directly related to the present study area. The authors made a limited effort to encapsulate perception on various services of off-season visited tourist to Cox's Bazar beach area. Ahmed (2010), examined tourism development and its impact on social, environmental, and local livelihood patterns of Cox's Bazar tourist area. All those studies did not reflect the expectation and attitudes of the local and international tourists or visitors to develop the strategies relate to the development of this sector. The present study looks into the measurement of tourist's attitude toward beach management systems and reorienting the strategies for developing this sector for sustainable development.

\subsection{Result and Discussion}

The following table shows the various factors that affect the tourists' attitude toward Beach management. The factors are measured by differential scale where 5= Excellent, $4=$ Very Good, $3.5=$ Good, 3=Average, $2.5=$ Not good, 2 = Poor and 1= very Poor" to measure tourists attitude toward Beach Management in Bangladesh. In spot facilities and management, the mean value is 3.20 which represents tourists are neutral about these facilities. It indicates that some attributes of those facilities should improve for attracting more tourists toward Beach. In the case of food and accommodation facilities, the mean value is 3.54 represents that tourists are more or less satisfied with that service in Beach Area. 
Table- 03: Tourist's attitude towards Beach Management in Bangladesh

\begin{tabular}{|c|c|c|}
\hline & $\begin{array}{l}\text { Mean Value } \\
\text { (Out of 5.00) }\end{array}$ & Remark \\
\hline Spot Facilities and Management & 3.20 & Average \\
\hline Food and Accommodation & 3.54 & Good \\
\hline Securities Issues & 3.16 & Average \\
\hline Hygiene and Sanitation & 2.50 & Not Good \\
\hline Emergency and health care services & 2.92 & Not Good \\
\hline Shopping and Activities & 3.69 & Good \\
\hline Guide and Information facilities & 3.46 & Average \\
\hline Transportation and other Services & 3.22 & Average \\
\hline Overall & 3.21 & Average \\
\hline
\end{tabular}

\section{Source: The Author, based on survey and FGD}

In the case of securities issues, the mean value is 3.16 which indicate tourists are neutral about the present securities condition in the Beach area. Monitoring arrangements are not sufficient in that area and tourists don't feel safe in that area after sunset. For those reasons, security issues should be improved in the Beach area. Bizarrely, the table shows the mean value of hygiene and sanitation is 2.50 which indicates that the present condition of beach hygiene and sanitation is more or less at dissatisfactory level. There are insufficient toilets and washroom facilities, dress change facilities and waste disposal facilities near Beach area. The Emergency and health care services' mean value is 2.92 which represents that tourists are more or less neutral about this facility in the Beach area. Interesting to see that for shopping and activities, the above table shows the mean value is 3.69 which indicate tourists are more or less satisfied with that service in the Beach area. This table shows the mean value of the guide and information facilities is 3.46. It represents that tourists are neutral about the facilities in the Beach area. For Transportation and other services, the mean value is 3.22 which indicate tourists are neutral about the present condition of transportation and other services. Noteworthy to remember that the overall mean value of these 8 dimensions is $\mathbf{3 . 2 1}$ which represents that tourists are neutral about various factors in Beach management. Some factors must be improved to attract more tourists and create positive attitudes of tourists toward Beach in Bangladesh.

\section{Regression Analysis:}

Regression analysis is conducted to find the impact on the dependent variable if there is any change in independent variables. Here, the dependent variable is respondents level of satisfaction on beach management in Bangladesh and the independent variable is tourist's attitude on spot facilities and management, Tourist's attitude on food and accommodation facilities, Tourist's attitude on security issues, Tourist's attitude on hygiene and sanitation, Tourist's attitude on emergency and health care services, Tourist's attitude on guide and information, Tourist's attitude on transport facilities, Tourist's attitude on shopping facilities for the beach tourist. This study found respondents' level of satisfaction on beach management in Bangladesh is positively and significantly affected by all independent variables except shopping facilities (Table -04 and 05).

\section{Table -04: Model Summary}

\begin{tabular}{|c|c|c|c|c|c|c|c|c|c|}
\hline \multirow[b]{2}{*}{ Model } & \multirow[b]{2}{*}{$\mathrm{R}$} & \multirow[b]{2}{*}{ R Square } & \multirow[b]{2}{*}{$\begin{array}{c}\text { Adjusted R } \\
\text { Square }\end{array}$} & \multirow[b]{2}{*}{$\begin{array}{l}\text { Std. Error of } \\
\text { the Estimate }\end{array}$} & \multicolumn{5}{|c|}{ Change Statistics } \\
\hline & & & & & $\begin{array}{c}\text { R Square } \\
\text { Change }\end{array}$ & $\begin{array}{c}\text { F } \\
\text { Change }\end{array}$ & df1 & $\mathrm{df} 2$ & $\begin{array}{l}\text { Sig. F } \\
\text { Change }\end{array}$ \\
\hline 1 & $.861^{\mathrm{a}}$ & .814 & .797 & .235 & .314 & 17.754 & 8 & 310 & .000 \\
\hline
\end{tabular}


Table -05: Coefficients of regression

\begin{tabular}{|c|c|c|c|c|c|c|c|}
\hline & \multicolumn{2}{|c|}{$\begin{array}{l}\text { Unstandardized } \\
\text { Coefficients }\end{array}$} & \multirow{2}{*}{$\begin{array}{c}\text { Standardized } \\
\text { Coefficients } \\
\text { Beta } \\
\end{array}$} & \multirow[b]{2}{*}{$\mathrm{t}$} & \multirow[b]{2}{*}{ Sig. } & \multicolumn{2}{|c|}{$\begin{array}{c}95 \% \text { Confidence } \\
\text { Interval for B }\end{array}$} \\
\hline & B & Std. Error & & & & $\begin{array}{l}\text { Lower } \\
\text { Bound }\end{array}$ & $\begin{array}{l}\text { Upper } \\
\text { Bound }\end{array}$ \\
\hline (Constant) & .002 & .356 & & .005 & .996 & -.698 & .701 \\
\hline $\begin{array}{l}\text { Tourist's attitude on spot facilities and } \\
\text { management }\end{array}$ & .068 & .075 & .053 & .915 & .036 & -.079 & .215 \\
\hline $\begin{array}{l}\text { Tourist's attitude on food and } \\
\text { accommodation facilities for the beach } \\
\text { tourist }\end{array}$ & .235 & .075 & .179 & 3.119 & .002 & .087 & .384 \\
\hline $\begin{array}{l}\text { Tourist's attitude on securities for the } \\
\text { beach tourist }\end{array}$ & -.070 & .083 & -.044 & -.846 & .038 & -.234 & .093 \\
\hline $\begin{array}{l}\text { Tourist's attitude on hygiene and } \\
\text { sanitation facilities of the sea beach }\end{array}$ & .040 & .061 & .039 & 2.661 & .009 & -.079 & .159 \\
\hline $\begin{array}{l}\text { Tourist's attitude on emergency and } \\
\text { health care services in the sea beach } \\
\text { area }\end{array}$ & .348 & .063 & .337 & 5.486 & .000 & .223 & .473 \\
\hline $\begin{array}{l}\text { Tourist's attitude on guide and } \\
\text { information facilities for the beach } \\
\text { tourist }\end{array}$ & .038 & .057 & .041 & 2.670 & .003 & -.074 & .150 \\
\hline $\begin{array}{l}\text { Tourist's attitude on transport facilities } \\
\text { for the beach tourist }\end{array}$ & .288 & .066 & .233 & 4.383 & .000 & .159 & .417 \\
\hline $\begin{array}{l}\text { Tourist's attitude on shopping facilities } \\
\text { for the beach tourist }\end{array}$ & -.030 & .077 & -.022 & -.395 & .693 & -.182 & .121 \\
\hline $\begin{array}{l}\text { a. Dependent Variable: Respondent's } \\
\text { Bangladesh }\end{array}$ & vel & $t$ & Beach & an & & & \\
\hline
\end{tabular}

Findings, Conclusion, and Recommendations:

Firstly, the study found that the Beach management authority in Bangladesh fails to provide a pollution-free environment to their tourists. On the other hand, tourists can not enjoy the nightlife of the beach without being concerned about security; on top there is poor internet services and network coverage. (Table -A1) Strong Internet Services and Network Coverage should be ensured by the government (Table-A3). Secondly, the study found that Food quality near the beach area is not good and charges high prices comparing to quality. Likewise, Accommodation prices are not reasonable near the beach area and hotel charges high price during peak season. (Table-A1) Thirdly, the study identified that Monitoring Arrangements are not appropriate in the beach area and tourists avoid some less secured and vulnerable areas where different types of crimes have occurred. (Table -A1). The Government should charge Entry Fee for proper beach management and may use ICT for ensuring Beach Entry Security. In addition to that, authority should set CCTV cameras for ensuring Tourist's Safety. Fourthly, the study has identified that there are not sufficient toilets and washroom facilities and dress change facilities near the beaches. Similarly, Waste Disposal Facilities are poor in the beach area. For that reason, the Government should ensure sufficient Toilet and Washroom Facilities for Tourists near the beach. (Table-A3). Fifthly, the study found that Emergency, Health, and Medical Services are not adequate for tourists near the Beach area. (Table -A1). Emergency Services Arrangement should be guaranteed by Government and they can use CCTV for observation of Beach Bath to save from missing in the Sea (Table -A3). Besides, the government may use ICT for informing Weather Report to the Visitors. (Table-A3) and Health and Medical Services should be available near the Beach Area. Sixthly, the study has found that, Trained Tourist Guides are not enough and Tourist Information Centers are not available near the Beach. (Table -A1) Sufficient Tourist Information Centre should be ensured by the Government for attracting more foreign tourists towards the beaches in Bangladesh. (Table -A3). Seventhly, it is found that Road Infrastructure and Air- Railway services are not good for tourists in Bangladesh. The government should improve the Road and Transportation Infrastructure of the tourist area in Bangladesh to attract more domestic and foreign tourists. Finally, the study found that the respondent's level of satisfaction on Beach Management in Bangladesh is more or less at neutral level. So, the government should take the above initiatives to attract more domestic and foreign tourists toward Beach in Bangladesh. 


\section{References}

Ahamed, F., Azam, M.S.,\& Bose, T.K. (2010). Factor affecting the selection of tour destination in Bangladesh: an Empirical Analysis. International Journal of Business and Management, 5,(3).

Ahmed, 2010. Impact of Tourism in Cox's Bazar, Bangladesh, unpublished thesis, MSS, Brac University, Bangladesh.

Ansari, Mohammad Nayeem Aziz, Akter, Shahnaz, Hoq, and Muhammad Jahedul. (2006). "Environmental Impact of Tourism: A Case Study on St. Martin's Island.” Journal of Business and Technology, 1(1).

Butler, R.W. (1974). "The social implications of tourist development." Annals of Tourism Research, 6 (3).

Cooper, C.P., and Jackson, S. (1989). "Destination life-cycle: The Isle of Man case study." Annals of Tourism Research, Vol. 16 (3), pp.377-398.

Das, R.K., \& Chakrabotry, J. (2012). An evaluation study on tourism in Bangladesh. Research Journal of Finance and Accounting, 3, (1).

Davenport, J., \& Davenport, J.L. (2006). The impact of tourism and personal leisure transport on coastal environments: a review. Estuar. Coast. Shelf Sci. 67, 280 e292.

De Kadt, E.( 1979). "Social planning for tourism in developing countries.” Annals of Tourism Research, 6 (1), pp. $36-48$.

Edelmann, K.M.S. (1975). "Major problems of tourism growth in developing countries." Annals of Tourism Research, 6 (3), pp. 338-350.

Emaad, M. (2007). Tourism Development Strategies and Poverty Elimination. Problem and Perspectives in Management, 5, (1).

Ferdous, J. \& Faisal, H. (2014).Tourism Potentiality and Development of Bangladesh: Applicability of Pragmatic Governmental Management Policy. Journal of Management and Science, 4(1), 71-78.

Hasan S.R. (1992). "Problems and Prospects of Tourism Industry in Bangladesh"-, Bureau of Business Research, University of Dhaka, pp 14-15.

Hassan, M.M. Shahnewaz, M. 2014. Measuring Tourist Service Satisfaction at Destination: A Case Study of Cox's Bazar Sea Beach, Bangladesh, American Journal of Tourism Management 2014, 3(1): 32-43.

Hyma, B. and Wall, G. (1979). "Tourism in a developing area: The Case of Tamil Nadu, India."

Jafari, J. (1974). "The Socio-economic cost of tourism to developing countries. ” Annals of Tourism Research, 1(7), pp. 227-262.

Khandakar, S. 2014. Sustainable Tourism Development in Bangladesh: Strategies and Guidelines, 8 (1), 178-185.

Okazaki, Etsuko. 2008. “A Community-Based Tourism Model: Its Conception and Use.” Journal of Sustainable Tourism 16 (5), pp 511-529.

Sadler, P.G., and Archer, B.H. (1974). "The economic impact of tourism in developing countries. "Annals of Tourism Research, 3 (1), 15-32.

Salleh NHM, Idris SH, Shukor MS and Othman R (2013) Rangsangan motivasi ketibaan pelancong asing mengikut kawasan ke Malaysia. Jurnal Teknologi 64(1): 41-50

Sofique, M.A., \& Parveen, J.A. (2009). Economic Prospects and Constraints of Cox's Bazar Bangladesh-A Study. South Asian Journal of Tourism and Heritage, 2(1).

Sukiman, M. F., Omar, S. I., Muhibudin, M., \& Yussof, I. (2013). Tourist satisfaction as the key to destination survival in Pahang. Procedia - Social and Behavioral Sciences, 91, $78-87$. https://doi.org/10.1016/j.sbspro.2013.08.404

Tooman. A.L. (1997). Tourism and Development. Journal of Travel Research, 35, 33-40.

Tuhin, K.W. \& Majumder, T.H. (2015). An Appraisal of Tourism Industry Development in Bangladesh. European Journal of Business and Management, 3(3), 287-298.

UDD (2011). Preparation of Development Plan of Cox's Bazar Town and Sea Beach up to Teknaf, Ministry of Housing and Public Works, Government of the People's Republic of Bangladesh.

Wang, S., \& Qu, H. (2006). A study of tourists' satisfaction determinants in the context of the Pearl River Delta sub-regional destinations. Journal of Hospitality \& Leisure Marketing, 14(3), 49-63.

Weber, K. (1997). The assessment of tourist satisfaction using the expectancy disconfirmation theory: A study of the German travel market in Australia. Pacific Tourism Review, 1, 35-45

Witt, S.F.(1991). "Tourism in Cyprus, Balancing the benefits and costs.” Travel Management,

WTTC (2019) Travel and tourism economic impact 2018 Czech Republic. Available at: https://www.wttc. org//media/files/reports/economic-impact-research/countries-2018/czechrepublic2018.pdf (accessed 17 January 2019).

Zahir, U.A., Nazrul, I. \& Shafiqul, I. (2011). Opportunities of Tourism Sector in Bangladesh. International Journal of Research in Commerce, IT \& Management, 1(6), 10-17. 


\section{Appendix:}

Table-A1: Tourist Attitudes on Beach Management Systems in Bangladesh

\begin{tabular}{|c|c|c|c|c|c|c|c|}
\hline & $\begin{array}{l}\text { Strongly } \\
\text { Disagree }\end{array}$ & Disagree & Neutral & Agree & $\begin{array}{l}\text { Strongly } \\
\text { Agree }\end{array}$ & \multirow[t]{2}{*}{ Mean } & \multirow[t]{2}{*}{ S.D } \\
\hline & $\%$ & $\%$ & $\%$ & $\%$ & $\%$ & & \\
\hline $\begin{array}{l}\text { Tourist can enjoy the Scenery and Views of } \\
\text { Beach }\end{array}$ & 0 & 0.9 & 8.1 & 70.3 & 20.6 & 4.11 & 0.561 \\
\hline Pollution Free Nature and Environment in Beach & 11.9 & 43.8 & 19.7 & 19.1 & 5.6 & 2.63 & 1.093 \\
\hline $\begin{array}{l}\text { Easy, Relax and Noise Free Environment in } \\
\text { Beach Area }\end{array}$ & 14.1 & 40.3 & 18.4 & 19.7 & 7.5 & 2.66 & 1.163 \\
\hline Recreation Facilities are available in Beach Area & 8.1 & 23.1 & 16.9 & 40.6 & 11.2 & 3.24 & 1.166 \\
\hline Tourist can enjoy the Night Life of Beach & 5.9 & 24.7 & 22.5 & 31.6 & 15.3 & 3.26 & 1.162 \\
\hline $\begin{array}{lccc}\text { Internet } & \begin{array}{c}\text { Services and } \\
\text { Coverage's in Beach Area }\end{array} & \text { Strong } & \text { Network } \\
\end{array}$ & 14.7 & 37.2 & 26.6 & 16.6 & 5 & 2.6 & 1.081 \\
\hline Food Services are available near Beach Area & 4.1 & 19.7 & 16.2 & 45 & 15 & 3.47 & 1.091 \\
\hline Quality of Food is Good near Beach & 8.8 & 30.6 & 32.2 & 25.6 & 2.8 & 2.83 & 1 \\
\hline Price of Food is Reasonable near Beach & 18.8 & 44.1 & 20 & 12.5 & 4.7 & 2.4 & 1.073 \\
\hline $\begin{array}{l}\text { Accommodation Services are available near } \\
\text { Beach Area }\end{array}$ & 0.9 & 10 & 23.8 & 49.7 & 15.6 & 3.69 & 0.886 \\
\hline $\begin{array}{l}\text { Accommodation Price is Reasonable in Beach } \\
\text { Area }\end{array}$ & 12.5 & 29.1 & 31.6 & 20.9 & 5.9 & 2.79 & 1.094 \\
\hline Hotel Charges High Price during Peak Season & 0.9 & 3.1 & 15.9 & 45.6 & 34.4 & 4.09 & 0.84 \\
\hline Quality Services are Provided by Hotel Authority & 0.9 & 13.1 & 38.4 & 39.7 & 7.8 & 3.4 & 0.847 \\
\hline $\begin{array}{l}\text { Hotel Authority ensures Tourist's Financial and } \\
\text { Physical Security }\end{array}$ & 5.6 & 22.2 & 42.2 & 20.3 & 9.7 & 3.06 & 1.018 \\
\hline $\begin{array}{l}\text { Authority Charges Entry Fee for Entering into } \\
\text { Beach Area }\end{array}$ & 26.2 & 44.7 & 19.7 & 8.4 & 0.9 & 2.13 & 0.931 \\
\hline $\begin{array}{l}\text { Monitoring Arrangement are sufficient in Beach } \\
\text { Area }\end{array}$ & 10.6 & 37.2 & 32.2 & 18.1 & 1.9 & 2.63 & 0.96 \\
\hline Tourist's Feel Safe in Beach Area & 21.2 & 41.9 & 24.4 & 12.5 & 0 & 2.28 & 0.938 \\
\hline $\begin{array}{l}\text { Tourists are Avoid some less secured and } \\
\text { vulnerable Area }\end{array}$ & 0 & 7.2 & 15.9 & 56.2 & 20.6 & 3.9 & 0.804 \\
\hline $\begin{array}{l}\text { Different Types of Crime are occurred in Beach } \\
\text { Area }\end{array}$ & 2.8 & 10.3 & 15.3 & 42.5 & 29.1 & 3.85 & 1.044 \\
\hline $\begin{array}{l}\text { Public Toilets and Washroom Facilities are } \\
\text { sufficient near Beach Area }\end{array}$ & 22.8 & 50.9 & 11.9 & 11.9 & 2.5 & 2.2 & 1.004 \\
\hline Dress Change Facilities are available near Beach & 30 & 46.6 & 14.1 & 8.1 & 1.2 & 2.04 & 0.938 \\
\hline Beach Area is Clean & 21.6 & 45.3 & 23.8 & 5.9 & 3.4 & 2.24 & 0.971 \\
\hline $\begin{array}{l}\text { Waste Disposal Facilities are available in Beach } \\
\text { Area }\end{array}$ & 20.9 & 46.9 & 17.8 & 9.7 & 4.7 & 2.3 & 1.053 \\
\hline $\begin{array}{l}\text { Tourist's Child Caring Facilities are available in } \\
\text { Beach Area }\end{array}$ & 10.9 & 43.4 & 27.5 & 14.7 & 3.4 & 2.56 & 0.984 \\
\hline Emergency Services are available for Tourists & 6.9 & 29.1 & 36.2 & 24.4 & 3.4 & 2.88 & 0.968 \\
\hline $\begin{array}{l}\text { Health and Medical Services are available in } \\
\text { Beach Area }\end{array}$ & 8.1 & 39.7 & 39.1 & 11.9 & 0.9 & 2.58 & 0.839 \\
\hline $\begin{array}{l}\text { Playing, Driving and Horse Riding Facilities are } \\
\text { available in the Beach }\end{array}$ & 0 & 11.9 & 16.2 & 52.8 & 18.8 & 3.79 & 0.886 \\
\hline $\begin{array}{l}\text { Local Products are available in Burmese Market } \\
\text { near Beach }\end{array}$ & 0 & 5.9 & 13.4 & 60.6 & 19.7 & 3.94 & 0.754 \\
\hline Sea Products are available near Beach & 0 & 5.6 & 5.9 & 61.2 & 26.9 & 4.1 & 0.74 \\
\hline $\begin{array}{l}\text { Prices of Local and Sea Products are Reasonable } \\
\text { for Tourist }\end{array}$ & 12.5 & 28.1 & 30.9 & 24.7 & 3.4 & 2.78 & 1.061 \\
\hline $\begin{array}{l}\text { Cost of Surfing, Driving, and Horse Riding is } \\
\text { Reasonable }\end{array}$ & 9.4 & 36.6 & 22.2 & 23.1 & 8.4 & 2.85 & 1.138 \\
\hline Trained Tourist Guides are available in Beach & 9.1 & 20.6 & 32.8 & 27.2 & 10 & 3.08 & 1.114 \\
\hline $\begin{array}{l}\text { Tourist Information Center is available near } \\
\text { Beach }\end{array}$ & 7.8 & 30.9 & 31.9 & 25.6 & 3.4 & 2.86 & 1.001 \\
\hline $\begin{array}{l}\text { Local People have Positive Attitudes towards } \\
\text { Tourists }\end{array}$ & 2.8 & 15.9 & 23.8 & 41.9 & 15.3 & 3.51 & 1.024 \\
\hline Local Transportations are available near Beach & 1.2 & 11.6 & 16.2 & 61.6 & 9.1 & 3.66 & 0.846 \\
\hline Transportation Cost is Reasonable for Tourists & 11.6 & 26.2 & 28.8 & 29.4 & 3.8 & 2.87 & 1.077 \\
\hline Road Infrastructure is Good & 14.1 & 34.4 & 25.3 & 25 & 0.9 & 2.64 & 1.036 \\
\hline Financial Services are available near Beach Area & 10.9 & 14.7 & 33.1 & 34.7 & 6.2 & 3.11 & 1.085 \\
\hline
\end{tabular}


Table-A2: Tourist satisfaction on Beach Management Systems in Bangladesh

\begin{tabular}{|c|c|c|c|c|c|c|c|}
\hline & 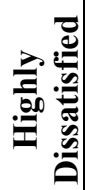 & 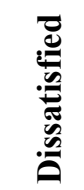 & 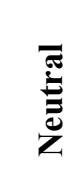 & 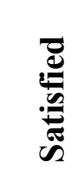 & 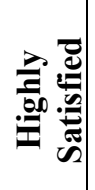 & \multirow[t]{2}{*}{$\sum_{\Sigma}^{\bar{E}}$} & \multirow[t]{2}{*}{$\stackrel{\theta}{\dot{s}}$} \\
\hline & $\%$ & $\%$ & $\%$ & $\%$ & $\%$ & & \\
\hline $\begin{array}{l}\text { Respondent's Level of Satisfaction on Overall Tourist's } \\
\text { Facilities in Bangladesh }\end{array}$ & 0.9 & 34.4 & 37.2 & 25.6 & 1.9 & 3.07 & 0.84 \\
\hline $\begin{array}{l}\text { Respondent's Level of Satisfaction on overall Beach } \\
\text { Management systems in Bangladesh }\end{array}$ & 0.9 & 26.9 & 37.2 & 30.9 & 4.1 & 2.9 & 0.88 \\
\hline $\begin{array}{l}\text { Tourist's attitude on spot facilities and management of the } \\
\text { sea beach }\end{array}$ & 0 & 12.5 & 57.5 & 27.2 & 2.8 & 3.2 & 0.68 \\
\hline $\begin{array}{l}\text { Tourist's attitude on food and accommodation facilities } \\
\text { for the beach tourist }\end{array}$ & 0 & 4.1 & 43.8 & 46.6 & 5.6 & 3.54 & 0.66 \\
\hline Tourist's attitude on securities for the beach tourist & 0 & 7.8 & 68.1 & 24.1 & 0 & 3.16 & 0.54 \\
\hline $\begin{array}{l}\text { Tourist's attitude on hygiene and sanitation facilities of } \\
\text { the sea beach }\end{array}$ & 6.9 & 49.7 & 31.9 & 9.1 & 2.5 & 2.51 & 0.85 \\
\hline $\begin{array}{l}\text { Tourist's attitude on emergency and health care services } \\
\text { in the sea beach area }\end{array}$ & 3.1 & 28.4 & 43.8 & 22.5 & 2.2 & 2.92 & 0.85 \\
\hline $\begin{array}{l}\text { Tourist's attitude on guide and information facilities for } \\
\text { the beach tourist }\end{array}$ & 2.8 & 10 & 38.4 & 35.3 & 13.1 & 3.46 & 0.94 \\
\hline $\begin{array}{l}\text { Tourist's attitude on transport facilities for the beach } \\
\text { tourist }\end{array}$ & 0.9 & 12.8 & 50.3 & 34.7 & 0.9 & 3.22 & 0.71 \\
\hline $\begin{array}{l}\text { Tourist's attitude on shopping facilities for the beach } \\
\text { tourist }\end{array}$ & 0 & 0 & 40.3 & 50.3 & 9.1 & 3.69 & 0.63 \\
\hline
\end{tabular}

Table -A3: Tourists' opinion to improve Beach Management Systems in Bangladesh

\begin{tabular}{|l|c|c|c|c|c|c|c|}
\hline & $\begin{array}{c}\text { Strongly } \\
\text { Disagree }\end{array}$ & Disagree & Neutral & Agree & $\begin{array}{c}\text { Strongly } \\
\text { Agree }\end{array}$ & Mean & S.D \\
\hline $\begin{array}{l}\text { Strong Internet Services and } \\
\text { Network Coverage should be } \\
\text { ensured }\end{array}$ & 6.2 & 9.7 & 13.4 & 30 & 40.3 & 3.89 & 1.218 \\
\hline $\begin{array}{l}\text { Authority should set CCTV } \\
\text { camera for ensuring Tourist's } \\
\text { Safety }\end{array}$ & 6.6 & 5.9 & 10.3 & 35.3 & 41.6 & 4 & 1.164 \\
\hline $\begin{array}{l}\text { Government should charge Entry } \\
\text { Fee for Beach Management }\end{array}$ & 20 & 20.3 & 17.2 & 19.7 & 22.5 & 3.04 & 1.453 \\
\hline $\begin{array}{l}\text { Government should ensure } \\
\text { sufficient Toilet and Washroom } \\
\text { Facilities for Tourist }\end{array}$ & 0.9 & 5 & 4.1 & 31.6 & 58.1 & 4.41 & 0.86 \\
\hline $\begin{array}{l}\text { Health and Medical Services } \\
\text { should be available near Beach } \\
\text { Area }\end{array}$ & 1.9 & 6.2 & 1.2 & 31.2 & 59.1 & 4.4 & 0.932 \\
\hline $\begin{array}{l}\text { Emergency Services } \\
\text { Arrangement should be ensured } \\
\text { by Government }\end{array}$ & 0.9 & 5.9 & 3.1 & 29.4 & 60.3 & 4.43 & 0.883 \\
\hline $\begin{array}{l}\text { Financial Services Facilities } \\
\text { should be available near Beach } \\
\text { Area }\end{array}$ & 0 & 5.3 & 11.9 & 32.2 & 50.3 & 4.28 & 0.873 \\
\hline $\begin{array}{l}\text { Government should improve } \\
\text { Road and Transportation } \\
\text { Infrastructure }\end{array}$ & 0 & 3.1 & 4.4 & 30.6 & 61.6 & 4.51 & 0.726 \\
\hline
\end{tabular}




\begin{tabular}{|l|c|c|c|c|c|c|c|}
\hline & $\begin{array}{c}\text { Strongly } \\
\text { Disagree }\end{array}$ & Disagree & Neutral & Agree & $\begin{array}{c}\text { Strongly } \\
\text { Agree }\end{array}$ & Mean & S.D \\
\hline $\begin{array}{l}\text { Sufficient Tourist Information } \\
\text { Centre should be ensued by } \\
\text { Government }\end{array}$ & 1.2 & 4.1 & 4.1 & 28.8 & 61.6 & 4.46 & 0.853 \\
\hline $\begin{array}{l}\text { Beach Visiting Area should be } \\
\text { Protected }\end{array}$ & 1.2 & 4.1 & 8.1 & 32.2 & 54.1 & 4.34 & 0.886 \\
\hline $\begin{array}{l}\text { ICT may use for ensuring Beach } \\
\text { Entry Security }\end{array}$ & 0.9 & 13.4 & 15.6 & 45.9 & 23.8 & 3.78 & 0.987 \\
\hline $\begin{array}{l}\text { Web Camera may use to capture } \\
\text { Beach Visiting }\end{array}$ & 3.4 & 7.8 & 11.6 & 46.2 & 30.6 & 3.93 & 1.023 \\
\hline $\begin{array}{l}\text { Web Camera may use to observe } \\
\text { Beach Bath }\end{array}$ & 5 & 20.6 & 15.9 & 38.8 & 19.4 & 3.47 & 1.165 \\
\hline $\begin{array}{l}\text { Use CCTV for observation of } \\
\text { Beach Bath to save from missing } \\
\text { in the Sea }\end{array}$ & 1.9 & 10.9 & 15.9 & 32.2 & 38.8 & 3.95 & 1.076 \\
\hline $\begin{array}{l}\text { Use ICT for informing Weather } \\
\text { Report to the Visitors }\end{array}$ & 2.5 & 4.7 & 10.3 & 43.4 & 38.8 & 4.12 & 0.946 \\
\hline $\begin{array}{l}\text { Use ICT for informing Joar- } \\
\text { Bhata Message Report to the } \\
\text { Visitors }\end{array}$ & 1.2 & 3.1 & 7.2 & 41.6 & 46.6 & 4.29 & 0.832 \\
\hline $\begin{array}{l}\text { ICT can improve overall Beach } \\
\text { Security Systems in Bangladesh }\end{array}$ & 1.2 & 6.2 & 10.6 & 44.1 & 37.5 & 4.11 & 0.915 \\
\hline $\begin{array}{l}\text { Entry Charge can apply for } \\
\text { ensuring Beach Security on } \\
\text { Visitors }\end{array}$ & 17.2 & 17.2 & 22.5 & 29.7 & 13.1 & 3.04 & 1.3 \\
\hline
\end{tabular}

